\title{
Simultaneous biodegradation of organic (chlorophenols) and inorganic compounds from secondary sludge of pulp and paper mill by Eisenia fetida
}

\author{
Santosh Kumar Karn • Swapan Kumar Chakrabarti
}

Received: 4 May 2014/ Accepted: 3 February 2015/Published online: 15 February 2015

(c) The Author(s) 2015. This article is published with open access at Springerlink.com

\begin{abstract}
Background Present research communicates the role of Eisenia fetida in converting pulp and paper mill sludge into valuable products by removing the high concentration of different chlorophenols and metals present in the sludge. Results Pulp and paper mill sludge was toxic to Eisenia fetida and therefore, it was mixed with composted material in different ratio of experimental set up such as Set up: 1, (95:5), Set up: 2 (80:20) and Set up: 3 (50:50) on dry weight basis. We found very promising results by the application Eisenia fetida in the sludge. Eisenia fetida removed all the twelve different chlorophenols more than $95 \%$ from the sludge which is declared as carcinogenic compounds by United States Environmental Protection Agency (US-EPA) in 90 days of incubation. Heavy metals concentration was decreased significantly during the incubation period whereas some metal concentration was also increased in the sludge due to mineralization. Carbon (C) and Nitrogen $(\mathrm{N})$ were increased in the composted material, C:N ratio for Set 1 9:4 in Set 2 13:4 and Set 3 18:4 was observed which acts as soil conditioner. Whereas some other metals like $(\mathrm{Ca}, \mathrm{Mg}, \mathrm{Na}, \mathrm{K}, \mathrm{Fe}$ and $\mathrm{Zn}$ ) was increased that are essential for the plant growth. There was great reduction in adsorbable organic halogen (AOX) $95 \%$
\end{abstract}

\footnotetext{
S. K. Karn ( $\square)$

Key Laboratory of Marine Environmental Corrosion and Biofouling, Institute of Oceanology,

Chinese Academy of Sciences, No. 7 Nanhai Road,

Qingdao 266071, Shandong, China

e-mail: santoshkarn@gmail.com

S. K. Chakrabarti

Environment Management Division,

Thapar Centre for Industrial Research and Development,

Yamunanagar 135001, India
}

and extractable organic halogen (EOX) $90 \%$ as compare to control. Eisenia fetida also removed pentachlorophenol (PCP) from the sludge with artificially increased concentration about $100 \mathrm{mg} / \mathrm{kg}$.

Conclusions By observing chlorophenols concentration, metals and carbon-nitrogen ratio, Eisenia fetida is acting as a potential candidate for the reclamation of industrial sludge. The result indicated that vermicomposting with Eisenia fetida is better option to manage the sludge or convert the sludge into nutrient-rich composted material in a short span of time.

Keywords Eisenia fetida . Chlorophenols .

Vermicompost - Sludge · Pulp and paper mill · AOX . EOX $\cdot$ Metals

\section{Introduction}

The rapid increase in population and the increasing demand for industrial establishments overexploitation of available resources to meet human requirements have created problems such as pollution of the land, air and water environments. Pulp and paper mills generate significant amount of biodegradable sludge ( 34 and $105 \mathrm{~kg} / \mathrm{t}$ product in large and small paper mills, respectively) during the papermaking and pulp making stages (Pokhrel and Viraraghavan 2004). The disposal of industrial sludge from effluent treatment plant is a global concern to the industries not a unique problem for the pulp and paper industry. Among the four major modes of sludge disposal; sea discharge, landfill, incineration and land application, now a days most of industry disposing the sludge by only land application. According to the recent estimate carried out by the US-EPA (1991) half of the 6,500 municipal landfill sites have been 
closed by the end of the last century and another $54 \%$ of the remaining landfills will be closed within next 5 years. The final disposal route for excess sludge generated by wastewater treatment is becoming a serious issue mainly due to the growth of population and sludge accumulation in large cities and growth in the amount and complexity of the related industrial activities. For this reason, it is necessary to reduce the amount of sludge generation by improving the efficiency of the treatment methodologies and implementing new technologies able to use sludge as raw material for compost, generate biomolecules and energy.

To cope up with this problem United States undertook a long-term research and demonstration program involving all the segments of society from regulators to farmers for the utilization of biosolids for gainful purposes and to find a long-term solution. Organochlorines are found in the sludge produced at pulp and paper mills. Accounting for as much as four percent of the total weight of the material contaminated sludge is spread on the land, buried in landfills or incinerated releasing chlorinated by-products into the air including polychlorinated phenols and dioxins (Mantykoski et al. 1989). In forests where pulp mill sludge has been dumped chlorinated phenols/dioxins have accumulated in the tissues of field animals and caused biochemical effects in birds (ERT 1987). Vermicomposting are well-known processes for solid organic waste reclamation: the final product vermicompost can be used as sources of organic matter for soil amendment, as sources of nutrients for soil fertilization or as growing media constituents for soilless cultivation (González et al. 2010). Vermicomposting is a bio-oxidative process which engages earthworms and microorganisms. The microorganisms both in the earthworm guts and in the feedstock are responsible for the biochemical degradation of the organic matter while the earthworms are responsible for the fragmentation of the substrate which increases the surface area exposed to the microorganisms. Hence the earthworms directly modify the physical properties of the material and indirectly modify its chemical properties. It is well-established that a large number of organic wastes can be ingested by earthworms and egested as peat-like material termed as vermicompost. It is much more fragmented, porous and microbially active than parent material (Edwards 1988; Edwards and Bohlen 1996) due to humification and increased decomposition. Recent study conducted by Huang et al. (2014) found that changes physiochemical properties and microbial profiles during vermicomposting to make the reliable material and Hanc and Chadimova (2014) found nutrient recovery after vermicomposting. Due to the certain limitations of the other processes, vermicomposting receiving more attention for stabilization of various wastes including for decreased duration of treatment process, increased pathogen reduction and better product quality (Hait and Tare 2011). Butt (1993) showed that solid paper mill sludge was a suitable feed for Lumbricus terrestis under laboratory conditions. Elvira et al. (1998) have also reported vermicomposting of paper mill sludge using Eisenia andrei under laboratory as well as field conditions. Gajalakshmi et al. (2002) studied the vermicomposting of paper waste using anecic earthworm Lampito mauriti. Today this is needful to treat the industrial sludge for the removal of organic and inorganic contaminants and manage it properly for the useful application; therefore, present study deals with the treatment of chlorophenols and inorganic constituents from the sludge of pulp and paper mill using Eisenia fetida further it can be applied as a compost material.

\section{Materials and methods}

\section{Collection of sludge sample}

Dewatered secondary sludge samples of pulp and paper mill were collected from the effluent treatment plant of BILT, Unit-Shree Gopal, Yamunanagar, Haryana, India. This mill adopts kraft process for pulping of raw materials mainly eucalyptus, poplar and bamboo. The effluent and sludge generated by the process is treated in activated sludge process for the biological removal of organics.

\section{Vermicomposting set up}

Dewatered secondary sludge was collected in large-sized plastic containers and then brought to the laboratory for further processing. Sludge was mixed with composted material in different proportions Set up: 1 (95:5) Set up: 2 (80:20) and Set up: 3 50:50) to maintain the moisture content and reduce the toxicity level of the secondary sludge for the adaptation of worms. Vermicomposting experiments were performed in plastic trays. No external addition of Nitrogen ( $\mathrm{N}$ ) and Phosphorus (P) was added during vermicomposting. $\mathrm{pH}$, temperature and moisture were maintained in the range of $7.5-8.5 ; 27-30{ }^{\circ} \mathrm{C}$ and 60-75\%, respectively throughout the period of study (for 90 days). The trays were covered with a jute mat and were kept in the shed. The composted material with earthworm $1 \mathrm{~kg}$ was spread and mixed at the top layer. Normally (1 kg worms present in $10 \mathrm{~kg}$ dry material). Earthworm species Eisenia fetida were obtained from a stock culture of Krishi Vigyan Kendra (KVK) Tepla Ambala, Haryana an ICAR unit of Govt. of India, with decomposed cow dung spiked with plant litters. Wheat straws (WS) were used to prepare as bedding materials for the experiments.

Further in another set chlorophenols degradation ability E. fetida was observed in sludge (proportion like set up: 2) 
with artificially spiked concentration of PCP in the sludge at the rate of $100 \mathrm{mg} / \mathrm{kg}$ and mixed thoroughly in plastic trays mentioned above and inoculated E. fetida and incubated under the same condition for 3 months. The tray were covered with jute mate to maintain the $\mathrm{pH}$; temperature, moisture as mentioned as before.

\section{Sludge characterization}

The sludge sample were analysed for physiochemical characteristic such as moisture, $\mathrm{pH}$, carbon, hydrogen, nitrogen, sulphur, zeta potential, absorbable organic halogen (AOX) and extractable organic halogen (EOX). Two grams of sludge sample was taken and dried into oven at $105{ }^{\circ} \mathrm{C}$ for $24 \mathrm{~h}$. The sample was then grinded in mortar pestle to get particles having size of about $0.1 \mathrm{~mm}$. The dried sludge sample (10-100 mg) was taken for CHNS analysis using Elemental analyzer (Thermo Scientific, USA). Zeta potential was analysed by maintaining $\mathrm{pH}$ of the sample to neutral and placing the sample in zeta potential analyzer, Muteck SZP06 (BTG Mutek GmbH, Germany). The AOX and EOX concentrations were determined using Euroglas Netherlands instrument ECS2000 according to the manufacturer's recommended procedure.

\section{Determination of chlorophenol}

Chlorophenols extraction and analysis was done by (NCASI (1986) method CP-85.01) method with a little modification. Secondary sludge samples were taken in ice bath and sonicated using a Sonicator (SG-25) Roop Telesonic Ultrasonics Ltd. India with variable power intensity between 3 and $7.4 \mathrm{~W} / \mathrm{cm}^{2}$ and a frequency of $24 \mathrm{kHz}$. The sample was immersed in ice and sonicated for total of 10 min with $1.5 \mathrm{~min}$ burst followed by $5 \mathrm{~min}$ rest in ice. Next added $1.3 \mathrm{ml} \mathrm{K}_{2} \mathrm{CO}_{3}(\mathrm{pH} 11.5)$ again sonicated for $2 \mathrm{~min}$ and added $1.5 \mathrm{ml}$ of acetic anhydride and sonicated for $2 \mathrm{~min}$ again added $0.5 \mathrm{ml}$ acetic anhydride further added $5 \mathrm{ml}$ of hexane and again sonicated and centrifuged and further extracted with hexane. After centrifugation at $10,000 \mathrm{rpm}$ for $15 \mathrm{~min}$, the supernatant was used to analyse the chlorophenols.

The GC analysis were performed in electron capture detection mode with a gas chromatograph Nucon GC-5765 (Centurion Scientific, India) capillary column DB-5 (30 meter length $0.025 \mathrm{~mm}$ i.d. $0.25 \mu \mathrm{m}$ film thickness) was used at a temperature program of $50{ }^{\circ} \mathrm{C}(2 \mathrm{~min})$ then raised to $10{ }^{\circ} \mathrm{C} / \mathrm{min}$ to $280{ }^{\circ} \mathrm{C}$ where it was held for $10 \mathrm{~min}$. Helium was used as the carrier gas at a constant flow of $1.2 \mathrm{ml} / \mathrm{min}$. The samples were analysed in splitless mode at an injection temperature of $250{ }^{\circ} \mathrm{C}$ and detector temperature $280{ }^{\circ} \mathrm{C}$. The injected volume was $0.1 \mu$ l.

\section{Determination of metals}

Metals was determined as per (APHA 1995) first sludge sample was digested with nitric and perchloric acid (3:1) and filtered through Whatman no. 42 paper. The filtrate was used for characterization of phosphorus content and the trace elements were analysed on furnace atomic absorption spectroscopy (AAS) and rest were analysed on flame AAS. The hydride forming elements were analysed using hydride generator.

\section{Statistical analysis}

Data were statistically analysed by analysis of variance (ANOVA) and the mean differences were compared by Tukey-Kramer Multiple Comparison Test at $p<0.05$. All experiments were performed in three replicates and analyses were performed using GraphPad Prism (v 4.03) software. (CA, USA).

\section{Results and discussion}

\section{Characterizations of sludge}

In recent time, interest for vermicomposting (using earthworms to breakdown organic materials) has increased (Hand 1988; Edwards 1988; Edwards and Bohlen 1996) due to its potential. In its basic form, this is a low-cost technology system that primarily uses earthworms in the processing or treatment of organic wastes (Hand 1988). Certain species of earthworm can consume organic material residuals very rapidly and fragment them into much finer particles and reducing the pollutants by passing them through a grinding gizzard. The earthworms derive their nourishment from microorganisms that grow upon these materials. At the same time, they promote further microbial activity since the fecal material or casts that they produce is much more fragmented and microbially active than what they consume (Edwards 1988; Edwards and Bohlen 1996). During this process, the important plant nutrients in the material (particularly the $\mathrm{N}, \mathrm{K}, \mathrm{P}$ and $\mathrm{Ca}$ ) are released and converted through microbial action into forms that are much more soluble and available to plants than those in the parent compounds. Therefore, first, collected secondary sludge samples were characterized for various physical and chemical characteristics such as $\mathrm{pH}$, organic matter, CHNS, AOX, and EOX described in (Table 1). All the twelve different chlorophenols were also analysed and described in (Table 2) and metals are described in (Table 3). Sludge sample were rich in organic $\mathrm{C}, \mathrm{H}, \mathrm{N}$ and $\mathrm{S}$ content. Vermicomposted material significantly modified the physical and chemical properties of all sets mixtures. 
Table 1 Chemical characteristic of secondary sludge from pulp and paper mill and material containing Eisenia fetida

\begin{tabular}{lcc}
\hline Parameter & $\begin{array}{l}\text { Secondary } \\
\text { sludge }\end{array}$ & \multicolumn{1}{l}{$\begin{array}{l}\text { Material containing } \\
\text { worms }\end{array}$} \\
\hline Moisture (\%) & $89.5 \pm 2.1$ & $51.34 \pm 1.8$ \\
Organic (\%) & $72 \pm 1$ & $78 \pm 2.4$ \\
Carbon (\%) & $24.2 \pm 1.3$ & $27.1 \pm 2.1$ \\
Hydrogen (\%) & $5 \pm 0.5$ & $2.4 \pm 0.7$ \\
Nitrogen (\%) & $3.2 \pm 0.6$ & $1.5 \pm 0.05$ \\
Sulphar (\%) & $0.7 \pm 0.01$ & $0.5 \pm 0.01$ \\
Kjeldhal Nitrogen (\%) & $5.8 \pm 1.1$ & $2.2 \pm 0.6$ \\
AOX (mg/Kg) & $2,400 \pm 67$ & $580 \pm 11$ \\
EOX (mg/kg) & $812 \pm 16$ & $132 \pm 6$ \\
C/N ratio & $7.5 \pm 0.8$ & $8.4 \pm 0.3$ \\
Zeta potential (mv) & $-15.2 \pm 0.05$ & $-12.1 \pm 0.04$ \\
\hline
\end{tabular}

Values are given as (Mean $\pm \mathrm{SE})$

$N D$ not detected

Table 2 Chlorophenols concentration in secondary sludge from pulp and paper mill and also material containing Eisenia fetida

\begin{tabular}{lll}
$\begin{array}{l}\text { Chlorophenolic } \\
\text { compounds }\end{array}$ & $\begin{array}{l}\text { Secondary sludge } \\
(\mathrm{mg} / \mathrm{kg})\end{array}$ & $\begin{array}{l}\text { Material containing } \\
\text { worms }(\mathrm{mg} / \mathrm{kg})\end{array}$ \\
\hline 2,4,6-TCP & $0.351 \pm 0.02$ & $<0.011$ \\
2,4,5-TCP & $0.191 \pm 0.01$ & $\mathrm{ND}$ \\
2,3,4,5-Tetrachlorophenol & $0.154 \pm 0.06$ & $\mathrm{ND}$ \\
3,4,6-Trichloroguacol & $0.153 \pm 0.03$ & $\mathrm{ND}$ \\
3,4,5-Trichloroguacol & $0.123 \pm 0.02$ & $\mathrm{ND}$ \\
4,5,6-Trichloroguacol & $0.143 \pm 0.04$ & $\mathrm{ND}$ \\
3,4,6-Trichlorocatecol & $0.322 \pm 0.07$ & $\mathrm{ND}$ \\
3,4,5-Trichlorocatecol & $0.373 \pm 0.01$ & $\mathrm{ND}$ \\
Tetrachloroguaiacol & $0.362 \pm 0.01$ & $\mathrm{ND}$ \\
Tetrachlorocatecol & $0.312 \pm 0.02$ & $\mathrm{ND}$ \\
Trichlorosyringol & $0.299 \pm 0.01$ & 0.05 \\
Pentachlorophenol & $0.345 \pm 0.01$ & $\mathrm{ND}$
\end{tabular}

Values are given as (Mean $\pm \mathrm{SE}$ )

$N D$ not detected

The vermicompost was much darker in color than before and has been processed more homogeneous mixture after 90 days of earthworm activity, the $\mathrm{pH}$ observed normal about 7.2 in the final vermicompost. Organic percentages were increased after composting for Set 1 it increased $36 \%$ for Set 2; $35 \%$ whereas for Set 3, it increased up to $50 \%$. The C:N ratio, one of the most widely used indicating for maturity of organic waste. In our experiments $\mathrm{C}: \mathrm{N}$ ratio was between 9.4 and 18.4 after 90 days of worms activity. In Set 1, we observed 9:4; in Set 2, 13:4 and Set 3, 18:4. In initial stage, C:N ratio was 8:4 for Set 1, 9:3 for Set 2 and was 14:3 for Set 3. According to Senesi (1989) a decline of
Table 3 Metallic characterizations of secondary sludge and material containing Eisenia fetida

\begin{tabular}{lll}
\hline Metals & $\begin{array}{l}\text { Secondary sludge } \\
(\mathrm{mg} / \mathrm{kg})\end{array}$ & $\begin{array}{l}\text { Material containing } \\
\text { worms }(\mathrm{mg} / \mathrm{kg})\end{array}$ \\
\hline $\mathrm{Na}$ & $1,300 \pm 19$ & $2,110 \pm 43$ \\
$\mathrm{~K}$ & $2,600 \pm 26$ & $5,033 \pm 13$ \\
$\mathrm{Mg}$ & $5,423 \pm 12$ & $3,555 \pm 19$ \\
$\mathrm{Ca}$ & $1,400 \pm 23$ & $4,929 \pm 22$ \\
$\mathrm{Al}$ & $2,900 \pm 27$ & $943 \pm 12$ \\
$\mathrm{P}$ & $416 \pm 11$ & $368 \pm 11$ \\
$\mathrm{Fe}$ & $2,453 \pm 41$ & $1,791 \pm 33$ \\
$\mathrm{Cr}$ & $36 \pm 7$ & $2.8 \pm 0.7$ \\
$\mathrm{Mn}$ & $133 \pm 11$ & $127 \pm 2$ \\
$\mathrm{Co}$ & $2.0 \pm 0.3$ & $0.7 \pm 0.02$ \\
$\mathrm{Zn}$ & $19 \pm 3$ & $67 \pm 2$ \\
$\mathrm{Ni}$ & $24 \pm 1$ & $1.8 \pm 0.2$ \\
$\mathrm{Cu}$ & $87 \pm 4$ & $18 \pm 2$ \\
$\mathrm{Cd}$ & $2 \pm 0.05$ & $0.1 \pm 0.02$ \\
$\mathrm{~Pb}$ & $28 \pm 3$ & $3.2 \pm 0.2$ \\
$\mathrm{Hg}$ & $\mathrm{ND}$ & $\mathrm{ND}$ \\
$\mathrm{Se}$ & $\mathrm{ND}$ & $\mathrm{ND}$ \\
$\mathrm{As}$ & $\mathrm{ND}$ & $\mathrm{ND}$ \\
$\mathrm{Val}$ & &
\end{tabular}

Values are given as (Mean $\pm \mathrm{SE}$ )

$N D$ not detected

$\mathrm{C}: \mathrm{N}$ ratio to less than 20 indicates an advanced degree of organic matter stabilization and reflects a satisfactory degree of maturity of organic waste. Total $\mathrm{K}$ and $\mathrm{N}$ were also increased by the end of vermicomposting due to mineralization of organic matter. Previously Benitez et al. (2000) has also reported that decomposition of organic materials by earthworm accelerates the $\mathrm{N}$ mineralization process and subsequently changes the $\mathrm{N}$ profile of the substrate. Kaushik and Garg (2004) have reported a 2.0-3.2 fold increase in TKN during vermicomposting of textile mill sludge mixed with cow dung and wheat straw. Therefore, vermicomposting is a considerable technology for the waste or specially sludge to increase the soil nutrient condition. Different organochlorine contaminants like AOX and EOX in the sludge were analysed (described in Table 4). AOX values ranged from 451 to $5,140 \mathrm{mg} / \mathrm{kg}$ dry solids. However, 93-95\% decreases in the AOX and 90-92 \% decrease in EOX level, after composting which makes it less toxic more stable and reliable material for use. Earthworms accumulate many lipophilic organic pollutants from the surrounding soil environment not only through passive absorption through the body wall of the dissolved fraction in the interstitial water but also by intestinal uptake during the passage of soil through the gut. The accumulation increases as the concentration of the pollutant in the soil environment (Belfroid et al. 1995a, b). 


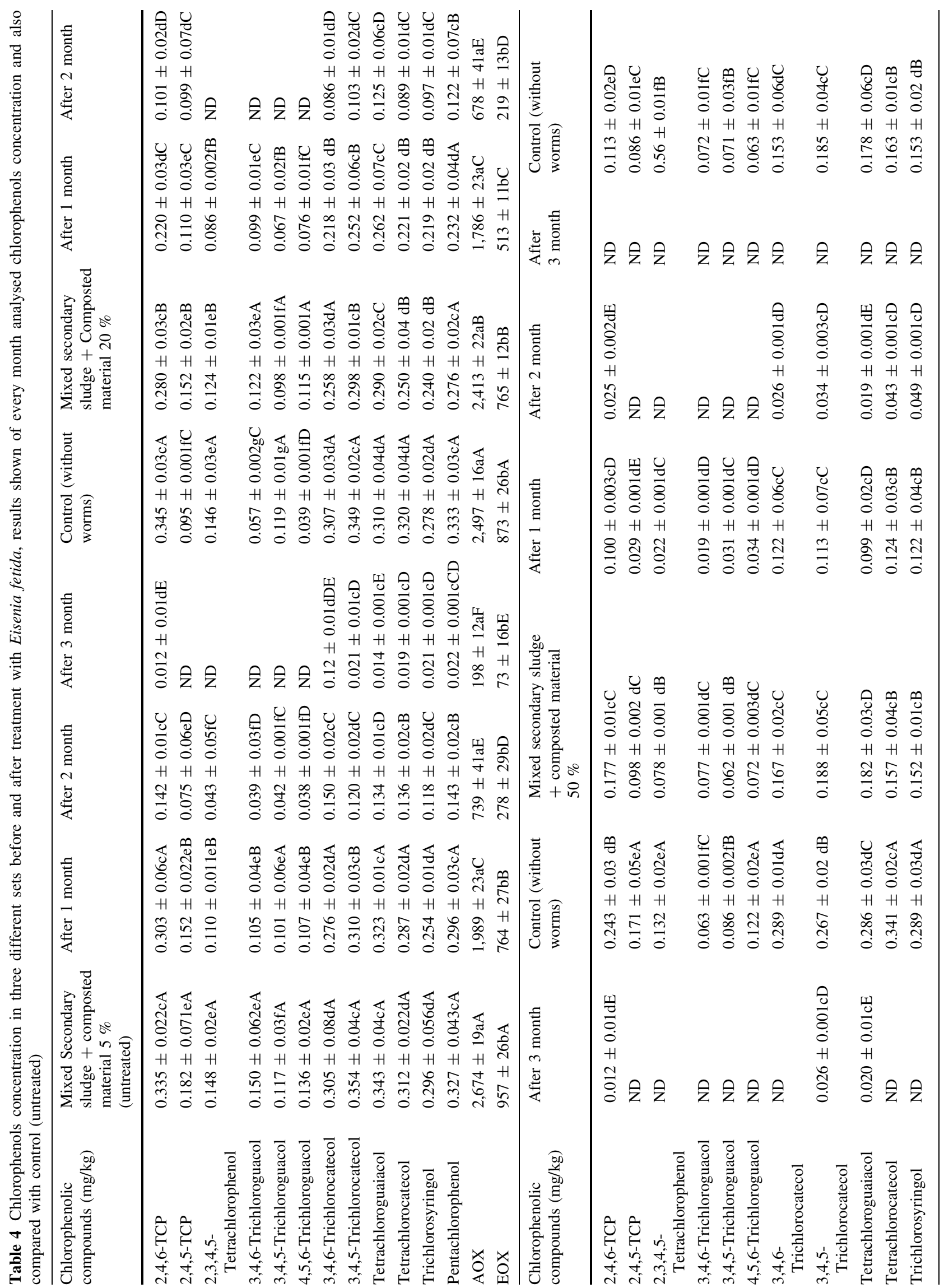


The secondary sludge sample was also characterized for 12 chlorophenolic compounds identified by USEPA as carcinogenic compound described in later section.

Chlorophenol concentration

Chlorophenols are important biocides and as by-product of bleaching in the pulp and paper industry. Their widespread use has resulted in broad distribution of these compounds in the environment. Environmental contamination with chlorophenols is widespread due to the importance of these chemicals as industrial intermediate, pesticides and solvents. Eisenia fetida can be a significant fate for the chlorophenol removal because physical and chemical methods are not feasible due to high cost and generate secondary pollutants and a single microorganism is unable to mineralize a wide range of different chlorophenols. Field and Sierra-Alvarez (2008) wrote a comprehensive review on the aerobic and anaerobic biotransformation of chlorophenols by microorganism. From the present result, we found that all the 12 different chlorophenols decreased significantly as compared to control having very high concentration (Table 4). Chlorophenols were decreased gradually with time; at 90 days from all the three sets, we did not observe any chlorophenols from the sample whereas in control chlorophenols, concentration was remaining the same (Table 4). From the 2nd experiment having spiked concentration of PCP about $(100 \mathrm{mg} / \mathrm{kg})$ after 90 days, we found that there is also significant decrease in the concentration of PCP and left about $0.02 \mathrm{mg} /$ $\mathrm{kg}$, which shows that vermicomposting having high potential for the removal of chlorophenol from the pulp and paper mill sludge. It is well-established that a large number of organic wastes can be ingested by earthworm and egested as peat-like material termed as vermicompost. Edwards (1988); Kaushik and Garg (2003, 2004) have reported the vermicomposting of textile mill sludge using Eisenia fetida. Butt (1993) showed that solid paper mill sludge was a suitable feed for Lumbricus terrestis under laboratory conditions. Elvira et al. (1998) have reported vermicomposting of paper mill sludge using Eisenia andrei under laboratory as well as field conditions and found suitable for mineralization and compost formation.

Some report also indicates that other annelids, such as aquatic Polychaetes, can metabolize benzopyrene, because they possess cytrochrome P450 enzymes capable of degrading this compound (Driscoll and McElroy 1997). The same enzymatic activity was found in terrestrial earthworms such as Eisenia fetida (Achazi et al. 1998). This may be a reason for Eisenia fetida to remove organic compounds and metabolize successfully. Autochthonous microorganisms degrade hydrocarbons (Johnsen et al. 2005), but if earthworms are added to soil, they will 


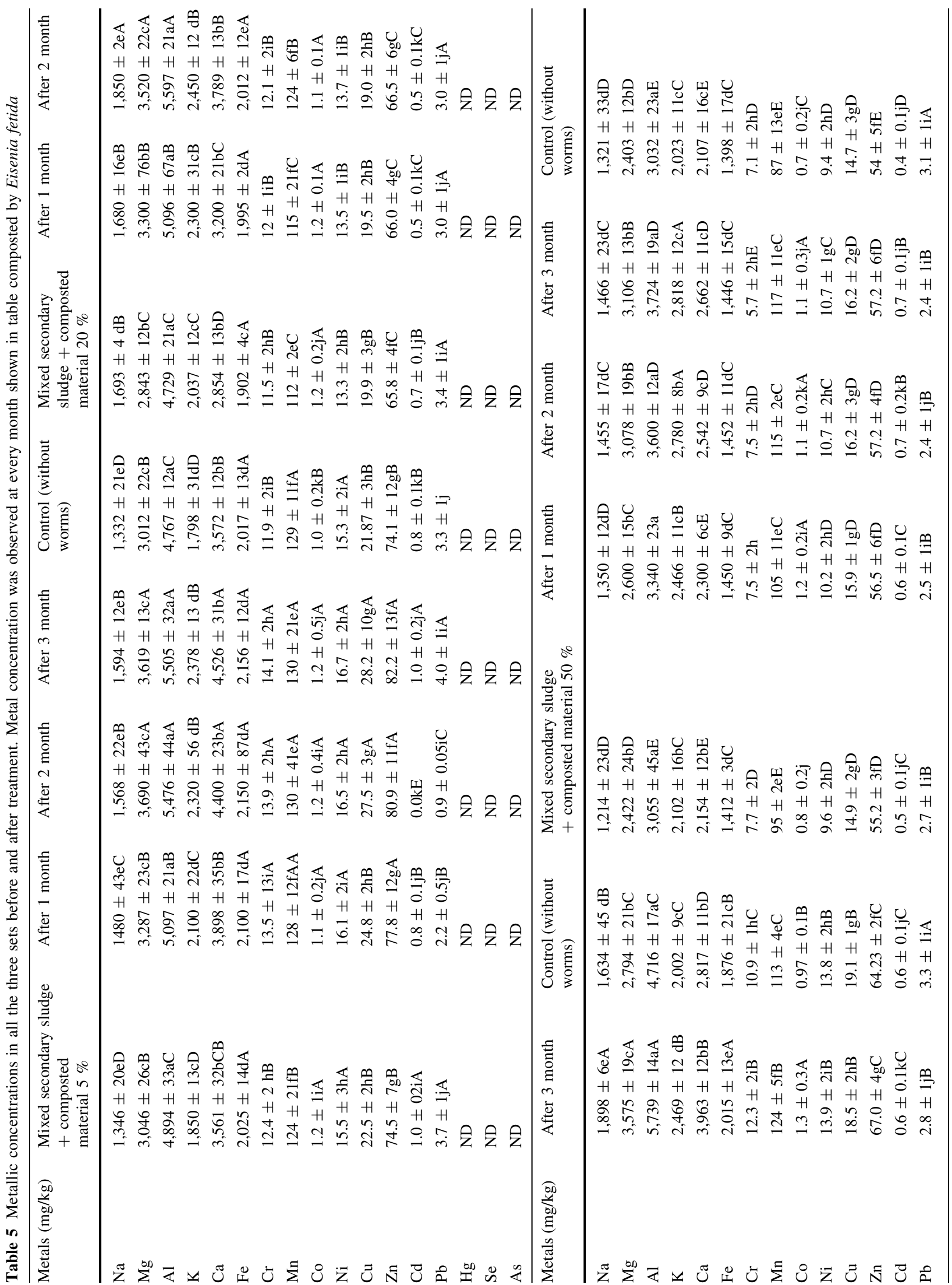




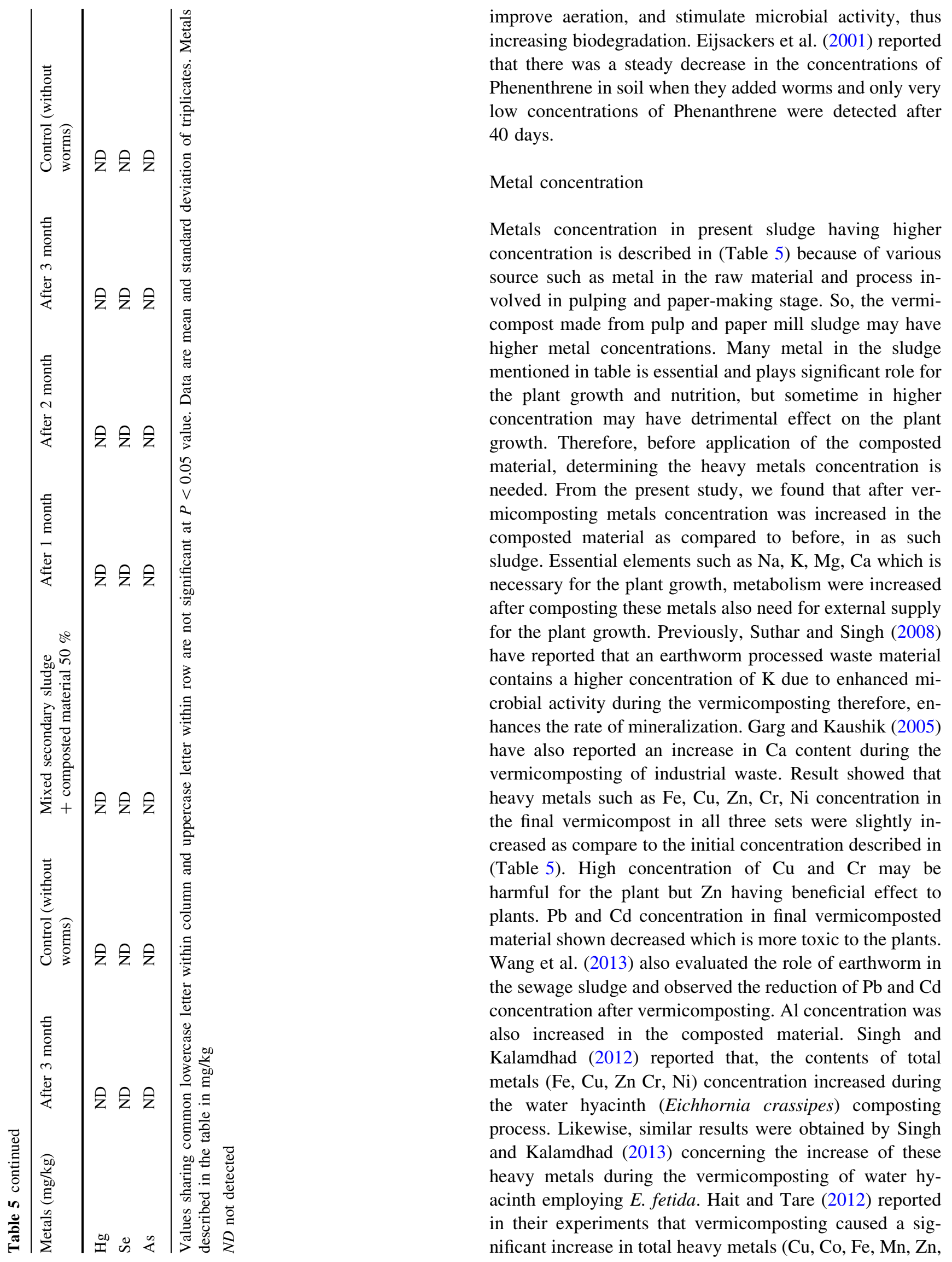


Cr) contents and a significant decrease in water-soluble heavy metals contents as compared to the compost material. Heavy metal like $\mathrm{Hg}$, $\mathrm{Se}$, As was not found in the present sludge. Metal such as Co, Mn was also increased which plays a major role as micronutrients and this result is supported by the finding of Hait and Tare (2012). Elvira et al. (1998) also reported an increase in heavy metals concentrations in vermicompost of paper mill sludge. Deolalikar et al. (2005) suggested that weight and volume reduction due to breakdown of organic matter during vermicomposting may be the reason for increase in heavy metal concentrations in vermicompost. In present results, we also observed weight loss which was about 13, 17 and $20 \%$ gradually for Set 1 , Set 2 and Set 3 .

\section{Conclusions}

We would like to recommend that earthworms (Eisenia fetida) have a great potential to remove chlorophenol from the sludge, even mineralize many metals that are resistant to degradation. Earthworm is extremely resistant to toxic chlorophenols and able to tolerate the high concentrations, normally not present in the soil. Applying Eisenia fetida to a contaminated sludge/site might be an environmentally friendly way to remove the chlorophenols.

Author contribution All the lab work was performed by SKK and suggestion was provided by SKC. Manuscript was prepared by SKK and checked by SKC. Both the authors have read and approved the final manuscript.

Acknowledgments The authors are thankful to KVK Tepla, for providing Eisenia fetida sp. and TCIRD Yamunanagar, for providing the industrial sludge and Biotechnology Engineering Department, Ambala College of Engineering and Applied Research for providing the facilities for the work.

Conflict of interest The authors declare that they have no competing interest.

Open Access This article is distributed under the terms of the Creative Commons Attribution License which permits any use, distribution, and reproduction in any medium, provided the original author(s) and the source are credited.

\section{References}

Achazi RK, Flenner C, Livingstone DR, Peters LD, Schaub K, Schiwe E (1998) Cytochrome P450 and dependent activity in unexposed and PAH-exposed terrestrial annelids. Comp Biochem Physiol C 121:339-350

APHA (1995) Standard methods for the examination of water and wastewater, 19th edn. American Public Health Association, American Water Works Association, Water Environment Federation, Washington, DC
Belfroid A, Meiling J, Drenth HJ, Hermens J, Seinen W, Gestel KV (1995a) Dietary uptake of super lipophilic compounds by earthworms (Eisenia andrei). Ecotoxicol Environ Saf $31: 185-191$

Belfroid A, Meiling J, Drenth HJ, Hermens J, Seinen W, Gestel KV (1995b) Dietary uptake of super lipophilic compounds by earthworms (Eisenia andrei). Ecotoxicol Environ Saf $31: 185-191$

Benitez E, Nogales R, Masciandro G, Ceccanti B (2000) Isolation by isoelectric focusing of humic urease complexes from earthworm (Eisenia fetida) processed sewage sludges. Biol Fert Soils 31:489-493

Butt KR (1993) Utilization of solid paper mill sludge and spent brewery yeast as a feed for soil-dwelling earthworms. Biores Technol 44:105-107

Deolalikar AV, Mitra A, Bhattacharyee S, Chakraborty S (2005) Effect of vermicomposting process on metal content of paper mill solid waste. J Env Sci Eng 47:81-84

Driscoll SBK, McElroy AE (1997) Elimination of sediment-associated benzopyrene and its metabolites by polychaete worms exposed to 3-methylcholanthrene. Aqu Toxicol 39:77-91

Edwards CA (1988) Breakdown of animal, vegetable and industrial organic wastes by earthworms. In: Edwards CA, Neuhauser EF (eds) Earthworms in waste and environmental management. SPB Academic Publishing, The Hague, pp 21-31

Edwards CA, Bohlen PJ (1996) Biology and ecology of earthworms. Chapman \& Hall, London

Eijsackers H, Van Gestel CAM, DeJonge S, Muijs B, Slijkerman D (2001) Polycyclic aromatic hydrocarbons-polluted dredged peat sediments and earthworms: a mutual interference. Ecotoxicology 10:35-50

Elvira C, Sampedro L, Benitez E, Nogales R (1998) Vermicomposting of sludge from paper mill and dairy industries with Eisenia andrei: a pilot scale study. Biores Technol 64:205-211

ERT (1987) A resource engineering company land treatment effects on wildlife populations in red pine plantations. Nekoosa Papers, Inc, Wisconsin, US

Field AJ, Sierra-Alvarez R (2008) Microbial degradation of chlorinated phenols. Rev Env Sci Biotech 7:211-241

Gajalakshmi S, Ramasamy EV, Abbasi SA (2002) Vermicomposting of paper waste with the anecic earthworm Lampito mauriti Kingburg. Int J Chem Technol 9:306-311

Garg VK, Kaushik P (2005) Vermistablisation of solid textile mill sludge spiked with poultry droppings by an epigeic earthworm Eisenia fetida. Biores Technol 96:1063-1071

González M, Gómez E, Comese R, Quesada M, Conti M (2010) Influence of organic amendments on soil quality potential indicators in an urban horticultural system. Biores Technol 101:8897-8901

Hait S, Tare V (2011) Optimizing vermistabilization of waste activated sludge using vermicompost as bulking material. Waste Manage 31:502-511

Hait S, Tare V (2012) Transformation and availability of nutrients and heavy metals during integrated composting vermicomposting of sewage sludges. Ecotoxicol Env Saf 79:214-224

Hanc A, Chadimova Z (2014) Nutrient recovery from apple pomace waste by vermicomposting technology. Biores Technol 168:240-244

Hand P (1988) Earthworm biotechnology (vermicomposting). In: Greenshields R (ed) Resources and applications of biotechnology. The Macmillan Press Ltd., London, pp 49-58

Huang K, Li Fusheng, Yongfen W, Xiaoyong F, Xuemin C (2014) Effects of earthworms on physicochemical properties and microbial profiles during vermicomposting of fresh fruit and vegetable wastes. Biores Technol 170:45-52 
Johnsen AR, Wick LY, Harms H (2005) Principles of microbial PAHdegradation in soil. Env Pollut 133:71-84

Kaushik P, Garg VK (2003) Vermicomposting of mixed solid textile mill sludge and cow dung with the epigeic earthworm Eisenia foetida. Biores Technol 90:311-316

Kaushik P, Garg VK (2004) Dynamics of biological and chemical parameters during vermicomposting of solid textile mill sludge mixed with cow dung and agricultural residues. Biores Technol 94:203-209

Mantykoski K, Paasivirta J, Mannila E (1989) Combustion products of biosludge from pulp mill. Chemosphere 19:413-416

NCASI method CP-85.01 (1986) NCASI methods for the analysis of chlorinated phenolics in pulp industry wastewater. National Council of the Paper Industry for Air and Stream Improvement, New York, USA

Pokhrel D, Viraraghavan T (2004) Treatment of pulp and paper mill wastewater a review. Sci Total Env 333:37-58

Senesi N (1989) Composted materials as organic fertilizers. Sci Total Env 81(82):521-524
Singh J, Kalamdhad AS (2012) Concentration and speciation of heavy metals during water hyacinth composting. Biores Technol 124:169-179

Singh J, Kalamdhad AS (2013) Effect of Eisenia fetida on speciation of heavy metals during vermicomposting of water hyacinth. Ecol Eng 60:214-223

Suthar S, Singh S (2008) Feasibility of vermicomposting in biostabilization of sludge from a distillery industry. Sci Total Environ 394:237-243

US Environmental Protection Agency (1991) Proposed regulation of land application of sludge from pulp and paper mills using chlorine and chlorine derivative bleaching processes. Fed. Reg. 56(91), 40 CFR. Part 744, OPTS-62100; FRL 3873

Wang L, Zheng Z, Zhang Y, Chao J, Gao Y, Luo X, Zhang J (2013) Biostabilization enhancement of heavy metals during the vermiremediation of sewage sludge with passivant. J Hazard Mater (244/245):1-9 